\title{
Benzinli Bir Motorda Yakıt Olarak Kullanılan Sodyum Borhidrür Katkılı Metanol-Benzin Karışımlı Yakıtların Performans ve Emisyon Analizi
}

\author{
Ahmet YAKIN $^{1 *}$, Rasim BEHÇET ${ }^{2}$ \\ ${ }^{1}$ Van Yüzüncü Yıl Üniversitesi, Van Meslek Yüksekokulu, Motorlu Araçlar Ve Ulaştırma Teknolojileri Bölümü, Van \\ ${ }^{2}$ Inönü Üniversitesi, Mühendislik Fakültesi, Makine Mühendisliği Bölümü, Malatya \\ (ORCID: 0000-0001-6716-2811) (ORCID: 0000-0002-6897-3066)
}

\begin{abstract}
Öz
Taşıtlarda kullanılan fosil kökenli yakıtların yakın gelecekte tükenecek olması, yerel olmaması, çevre ve insan sağlığ açısından zararlı etkilere sahip olmaları gibi nedenlerden dolayı alternatif yakıtlar gündeme gelmiştir. Hidrojen, biyoyakıtlar ve alkoller (etanol, metanol, bütanol vb.), yenilenebilir, yerel, temiz ve çevreye duyarlı alternatif yakıtlardır. Bu çalışmada, saf benzin, MB15 karışım yakıtı (hacimsel olarak \% 15 metanol ve \%85 benzin) ve MSB15 karışım yakıtı (hacimsel olarak \%15 sodyum borhidrür katkılı metanol çözeltisi ve \%85 benzin)'ından oluşan üç çeşit yakıt benzinli bir motorda test edilerek yakıtların motor performans ve egzoz emisyonları üzerindeki etkisi deneysel olarak araştırılmıştır. Motor test sonuçlarından elde edilen değerler birbirleri ile karşılaştırıldığında, saf benzine göre MB15 ve MSB15 karışım yakıtların $\mathrm{CO}$ emisyonları sırasıyla \% 63.17 ve \% 52.65 azalırken, HC emisyonları sırasıyla \% 15; \% 31.42 artmıştır. Ayrıca MB15 ve MSB15 karışım yakıtların motor momenti saf benzine göre sırasıyla \% 0.95 ve \% 2.24 artma meydana geldiği, özgül yakıt tüketiminde ise sırasıyla \% 3.27 ve \% 7.52 artma meydana gelmiştir. MB15 ve MSB15 karışım yakıtlarının motor gücü de saf benzin yakıtlı motor gücüne göre sırasıyla \% 1.18 ve \% 3.04 artmıştır.
\end{abstract}

Anahtar kelimeler: Metanol, Sodyum Borhidrür, Benzinli motor, Performans, Egzoz Emisyonu.

\section{Performance and Emission Analysis of Sodium Borohydride Additive Methanol-Gasoline Blended Fuels Used as Fuel in a Gasoline Engine}

\begin{abstract}
As the fossil fuels used in vehicles will be depleted in the near future due to not being local, having harmful effects on the environment and human health, alternative fuels have come to the fore due. Hydrogen, biofuels and alcohols (ethanol, methanol, butanol, etc.) are renewable, local, clean and environmentally friendly alternative fuels. In this study, three types of fuel consisting of pure gasoline, MB15 mixed fuel (15\% methanol and 85\% gasoline by volume) and MSB15 mixed fuel ( $15 \%$ sodium borohydride added methanol solution and $85 \%$ gasoline by volume) were tested in a gasoline engine. The effects of fuels on engine performance and exhaust emissions have been experimentally investigated. When the values obtained from the engine test results are compared with each other, the CO emissions of MB15 and MSB15 blended fuels decreased by $63.17 \%$ and $52.65 \%$, respectively, while the $\mathrm{HC}$ emissions were $15 \%$; Increased by $31.42 \%$. In addition to engine torque of MB15 and MSB15 mixed fuels increased by $0.95 \%$ and $2.24 \%$, respectively, compared to pure gasoline, specific fuel consumption increased by $3.27 \%$ and $7.52 \%$, respectively. Engine power of MB15 and MSB15 mixed fuels increased by $1.18 \%$ and $3.04 \%$, respectively, compared to pure gasoline engine power.
\end{abstract}

Keywords: Methanol, Sodium Borohydride, Gasoline engine, Performance, Exhaust Emission

\section{Giriş}

Taşıt kullanımında yakıt ekonomisi ve motor performansı önemli kriterler arasındadır. Teknolojideki ilerlemeler yakıt ekonomisini ve taşıt güvenliğini ön plana aldığında yeni teknolojiye sahip ulaşım araçlarını da beraberinde getirmiştir. Hem küresel 1sınmanın önüne geçmek hem de günümüz araçlarında kullanılan fosil kökenli yakıtlara alternatif olabilecek çevreye duyarlı, temiz ve yenilenebilir yakıtlar elde etmek için bilim adamları, yoğun bir çaba sarf etmektedirler. İçten yanmalı motorlarda fosil kökenli yakıtların yerine kullanılabilecek yakıtlardan biride alkol türevli yakıtlardır. Günümüzde

\footnotetext{
*Sorumlu yazar: ahmetyakin@yyu.edu.tr

Geliş Tarihi: 30.04.2021, Kabul Tarihi: 05.07.2021
} 
taşıt kaynaklı zararlı egzoz emisyonları azaltmak amacıyla en çok kullanılan yakıtlar arasında etanol ve metanol yer almaktadır.

Fosil kökenli yakıt olan petrolün tüketiminin artmasına paralel olarak hem fiyatlarındaki artış hem de çevreye verdiği zararlardan dolayı alternatif enerji kaynaklarının araştırılmasını zorunlu kılmaktadır [1-3]. Alkoller, benzin yakıtının oktan sayısını arttırarak zararlı egzoz emisyonlarını da azaltmaktadırlar. Bundan dolayı benzine alternatif yakıt olarak veya katkı maddesi olarak düşünülmektedir [4-5]. Benzin $\left(\mathrm{C}_{8} \mathrm{H}_{18}\right)$ yakıtında hem oktan sayısını arttırmak hem de zararlı egzoz emisyonlarının iyileştirilmesi amacıyla kullanılan katkı maddelerinin başında oksitleyici olarak da bilinen hafif alkoller (metanol, etanol vb.) gelmektedir [6-12]. Etanol $\left(\mathrm{C}_{2} \mathrm{H}_{6} \mathrm{O}\right)$ ve metanol $\left(\mathrm{CH}_{3} \mathrm{OH}\right)$, hem saf halde hem de benzine belirli oranlarda ilave edilerek benzinli motorlardan kaynaklanan egzoz emisyonlarını düşürmekle kalmayıp aynı zamanda yanma verimi ve motor performansını arttırabilmektedir. Alkoller, içerisinde bulundurdukları oksijen miktarının yüksek olması, gizli buharlaşma 1sısı, alev hızı ve tam yanma gibi olumlu özelliklerinden dolayı benzinli motorlarda hiçbir değişiklik yapılmadan yakıt olarak kullanılmaktadırlar [13-16].

Benzin (B100), etanol-benzin ve metanol-benzin karışımlarının benzinli motora sahip bir araçta yakıt olarak kullanıldığı çalışmada [17], araç performansı ve egzoz emisyonları üzerindeki etkilerini incelemiştir. Şasi dinamometresinde yapılan deney sonuçlarına göre, benzin ile çalışan araca göre, alkolbenzin karışımları ile çalışan aracın tekerlek gücü ve özgül yakıt tüketimi (ÖYT)'de hafif bir artış meydana geldiği gözlenmiştir. Taşıtlarda kullanılan yakıtların özelliklerini iyileştirmek ve bu yakıtların çevre ve insan sağlığı üzerindeki zararlı etkilerini azaltmak amacı ile son zamanlarda birçok bilimsel çalışma yapılmıştır. Hsieh ve arkadaşları [18], farklı oranlardaki etanol-benzin karışımlarını benzinli bir motorda test ederek karışım yakıtların motor performans ve egzoz emisyonları üzerindeki etkilerini incelemişler. Elde edilen test sonuçlarına göre karışım içerisindeki etanol miktarının artması ile motor torku ve özgül yakıt tüketimi artarken karışım içerisindeki etanol miktarının artması ile oluşan fakir karışımdan dolayı yanmamış HC (hidrokarbon) ve CO (karbon monoksit) emisyonlarının azaldığı gözlenmiştir. Rong-Horng ve arkadaşlarının içten yanmalı benzinli bir motorda yaptıkları çalışmada test motorunda yakıt olarak etanol-benzin karışımı yakıt kullanmışlardır. Karışım yakıtın test motorunun ilk çalışmasında meydana gelen emisyonların üzerindeki etkisini deneysel olarak incelemişlerdir. Deney sonuçlarına göre etanol oranının \%20'den fazla olması motorun ilk çalışma emisyonunu (CO, HC) önemli ölçüde azaltmaktadır [19].

Araştırma oktan sayısı değeri 123 ve motor oktan sayısı değeri 96 olan ve oktan arttırıcı olarak benzin içerisine hacimsel olarak 10 'un altında katılan veya hacimsel olarak $\% 85$ oranında alternatif yakıt olarak da kullanılan etanol, tarımsal ürünlerin, (şeker kamışı, şeker pancarı, mısır nişastası gibi kolayca şekere dönüştürülebilen ürünler) fermantasyonundan türetilen renksiz organik bir sıvı olarak tanımlanırken methanol, benzin içerisine oktan arttırıcı ve oksijenat olarak karıştırılır. Metanoldeki en büyük problem, faz ayrışmasıdır. Metanol su ile oldukça yüksek çözünürlüğü bulunan sıvı organik bir bileşiktir.. Methanol-Benzin karışımlarında faz ayrışması sorununu çözmek için veya karışımı tek fazda tutabilmek için TBA (Tertiary-Butyl Alcohol) kullanılmaktadır [20].

$\mathrm{Bu}$ çalışmada, \%15 metanol ve \%85 benzin homojen olarak karıştırılarak, MB15 olarak adlandırılan yakıt ile \%15 metanol içerisinde çözünmüş sodyum borhidrür çözeltisi \% 85 benzin ile homojen olarak karıştırılmasıyla MSB15 olarak adlandırılan karışım yakıt elde edilmiş̧tir. Benzin, MB15 ve MSB15 yakıtları tek silindirli ve su soğutmalı benzinli bir motorda önce benzin yakıtı olmak üzere test edilerek yakıtların motor performansı ve egzoz emisyonları üzerindeki etkisi deneysel olarak araştırılmıştır.

\section{Materyal ve Metot}

\subsection{Sodyum Borhidrür (NaBH4)}

Kimyasal formülü $\mathrm{NaBH}_{4}$ şeklinde olan sodyum borhidrür, günümüzde içerisinde bulundurduğu hidrojenden dolayı hidrojen depolama ve taşıma sistemlerinin oluşturulmasında büyük bir öneme sahiptir. Hidrojen üretimi için yüksek seviyede hidrojen depolama yoğunluğuna sahip olan saf $\mathrm{NaBH}_{4}$ ağırlıkça \%10.8 hidrojen içermektedir [21]. Tablo 2'de $\mathrm{NaBH}_{4}$ 'ün fiziksel özellikleri gösterilmektedir. 
Tablo 2. Sodyum bor hidrürün fiziksel özellikleri[22].

\begin{tabular}{|c|c|}
\hline Yakıt özellikleri & Sodyum Borhidrür \\
\hline Formülü & $\mathrm{NaBH}_{4}$ \\
\hline Yakıt ağırlığı (g/mol) & 37.84 \\
\hline Teorik $\mathrm{H}_{2}$ içeriği, \% (ağırlıkça) & 10.6 \\
\hline Kristal yapıs1 & Yüzey merkezli kübik $\left(\mathrm{a}=6.15 \mathrm{~A}^{0}\right)$ \\
\hline Kaynama noktası $1{ }^{0} \mathrm{C}$ & 505 \\
\hline Bozunma sıcaklı̆ğ $1,{ }^{0} \mathrm{C}$ & 315 \\
\hline Erime noktası, ${ }^{0} \mathrm{C}$ (2-6 atm $\mathrm{H}_{2}$ basıncında) & 500 \\
\hline Bozunma sıcaklı̆ı $1{ }^{\circ} \mathrm{C}$ (vakum altında) & 400 \\
\hline Oluşum entalpisi $\left(25^{\circ} \mathrm{C}\right), \mathrm{kJ} / \mathrm{mol}$ & -188.6 \\
\hline Oluşum Gibbs enerjisi $\left(25^{\circ} \mathrm{C}\right), \mathrm{kJ} / \mathrm{mol}$ & -123.9 \\
\hline Entropi, J.mol ${ }^{-1} . \mathrm{K}^{-1}$ & 101.3 \\
\hline Is1 kapasitesi $\left(25^{0} \mathrm{C}\right), \mathrm{J} . \mathrm{K}^{-1} . \mathrm{h}$ & 86.8 \\
\hline
\end{tabular}

\subsection{Metanol}

Benzine göre 1sıl değeri düşük, saydam, renksiz, kendi kendine tutuşma eğilimi düşük, kokusu hafif, buharlaşma 1sıs1 yüksek olan metanol, soğukta ilk hareketi zorlaştırmasına karşın volümetrik verimi arttırır özelliktedir. Ayrıca metanolün nem tutma özelliğine dolayı içerisinde bulunabilecek su nedeniyle yakıt sistemlerinde korozyona neden olabilmektedir. Benzinli motorlarda metanol yakıt olarak kullanıldığında, metanolün kendi kendine tutuşma direnci sayesinde sıkıştırma oranının artmasına imkân sağlamaktadır. Benzinli motorlarda, emme supabına gerek duyulmadan metanol silindir içerisine doğrudan püskürtülebilmektedir. Metanolün oktan sayısının yüksek olması nedeniyle sıkıştırma basıncının düşük olması durumlarında bile püskürtmede bir problem oluşturmamaktadır. Metanolün bu özelliklerinden dolayı yakıt sistemi basit ve ucuz olsa bile değişik motor yüklerinde motorun verimli olarak çalıştırılabilmesi mümkündür [23].

\section{3. $\mathrm{NaBH}_{4}$ Katkılı Karışım Yakıtlar}

$\mathrm{Bu}$ çalışmada, içten yanmalı benzinli motorlarda kullanılan yakıtlara alternatif olabilecek düşük emisyonlu karışım yakıtların üretilmesi hedeflenmiştir. Bu hedef doğrultusunda benzinli bir motorda test etmek amacıyla sodyum bor hidrür, metanol ve benzinden oluşan üç farklı hammadde kullanılarak, Şekil 1 de gösterildiği gibi karışım yakıtlar (MB15, MSB15) oluşturulmuştur.

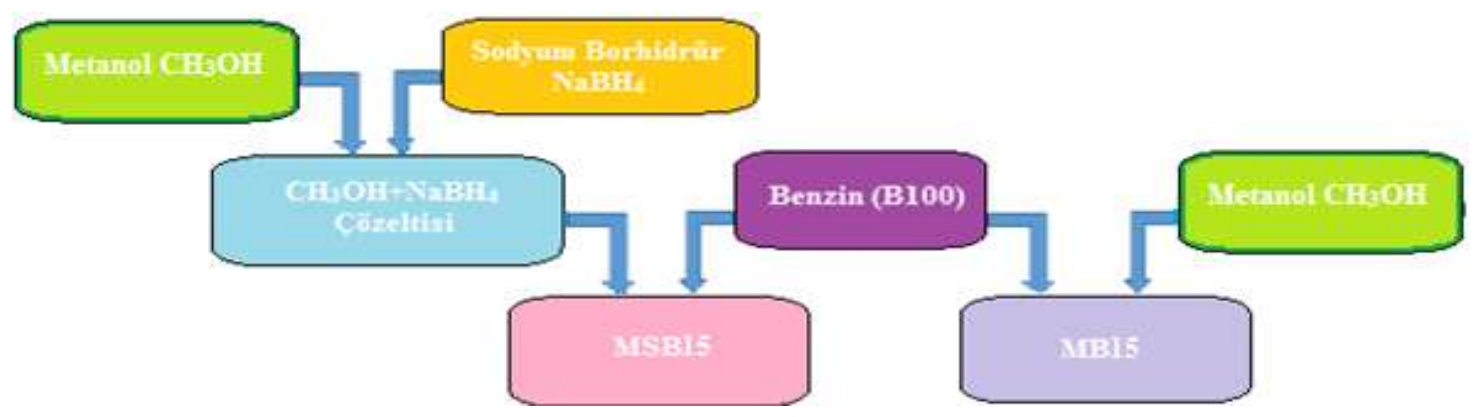

Şekil 1. Karışım yakıtların akış diyagramı

Elde edilen karışım yakıt maliyet bakımından yeniden değerlendirilerek maliyet ile ilgili gerekli hesaplamalar yapılmış olup karışım yakıtın maliyeti için yaklaşık olarak 7.98 TL'ye denk gelen bir fiyat elde edilmiştir. Güncel benzin fiyatlarının 8.13 TL olduğu göz önünde bulundurulduğunda karışım yakıtın benzine göre daha düşük fiyatta olduğu görülmektedir.

\subsection{Motor Deneyleri}

Deneyler, Gazi Üniversitesi Otomotiv Mühendisliği laboratuvarlarında yapılmıştır. Deneysel çalışma için tek silindirli, buji ateşlemeli, su soğutmalı deney motoru kullanılmıştır. Deneylerde kullanılan motorun teknik özellikleri Tablo 1'de verilmiştir. 
Deneylerin yapılışı şu şekilde gerçekleştirilmiştir: Test motoru önce benzinle çalıştırılarak motor kararlı rejime geldikten sonra deneyler yapılmaya başlanmış ve her deney 3 kez tekrarlanarak elde edilen sonuçların aritmetik ortalaması alınmıştır. Deneysel çalışma, motor tam yükte ve 1400 ile $3000 \mathrm{~d} / \mathrm{d}$ arasında değişen motor hızlarında yapılmıştır.

Tablo 1. Test motorunun özellikleri

\begin{tabular}{|l|l|}
\hline Özellik & Motor \\
\hline Marka & Ricardo Hydra \\
\hline Silindir sayısı & 1 \\
\hline Sıkıştırma oranı & $10: 1$ \\
\hline Maksimum hız $\left(\mathrm{min}^{-1}\right)$ & 5400 \\
\hline Maksimum güç $(\mathrm{kW})$ & $15 \mathrm{~kW}, 54001 / \mathrm{min}$ de \\
\hline Minimum hız (min $\left.{ }^{-1}\right)$ & 1200 \\
\hline Silindir çapı $(\mathrm{mm})$ & 80.26 \\
\hline Silindir kurs $(\mathrm{mm})$ & 88.90 \\
\hline Supap sistemi & Üstten kamlı iki supap \\
\hline Yakıt sistemi & Port tipi enjeksiyon \\
\hline Soğutma sistemi & Siv1 soğutmalı \\
\hline
\end{tabular}

Deney düzeneğinin şematik görünümü Şekil 2'de verilmiştir. Deneylerde motor performansının ölçülmesi için $6500 \mathrm{~d} / \mathrm{d}$ motor devrinde $30 \mathrm{~kW}$ gücü da absorbe edebilen, McClure marka elektrikli tip dinamometre kullanılmıştır. Test sisteminde yakıt tüketimi, analog olarak kayıt edilmiş ancak motor momenti ve motor yağ sıcaklığı, egzoz sıcaklığı dijital olarak kayıt edilmiştir. Yakıt deposu $0.01 \mathrm{~g}$ hassasiyetindeki terazi üzerine yerleştirilmiş ve motorun 60 saniyede tükettiği yakıt verisi kaydedilmiştir.

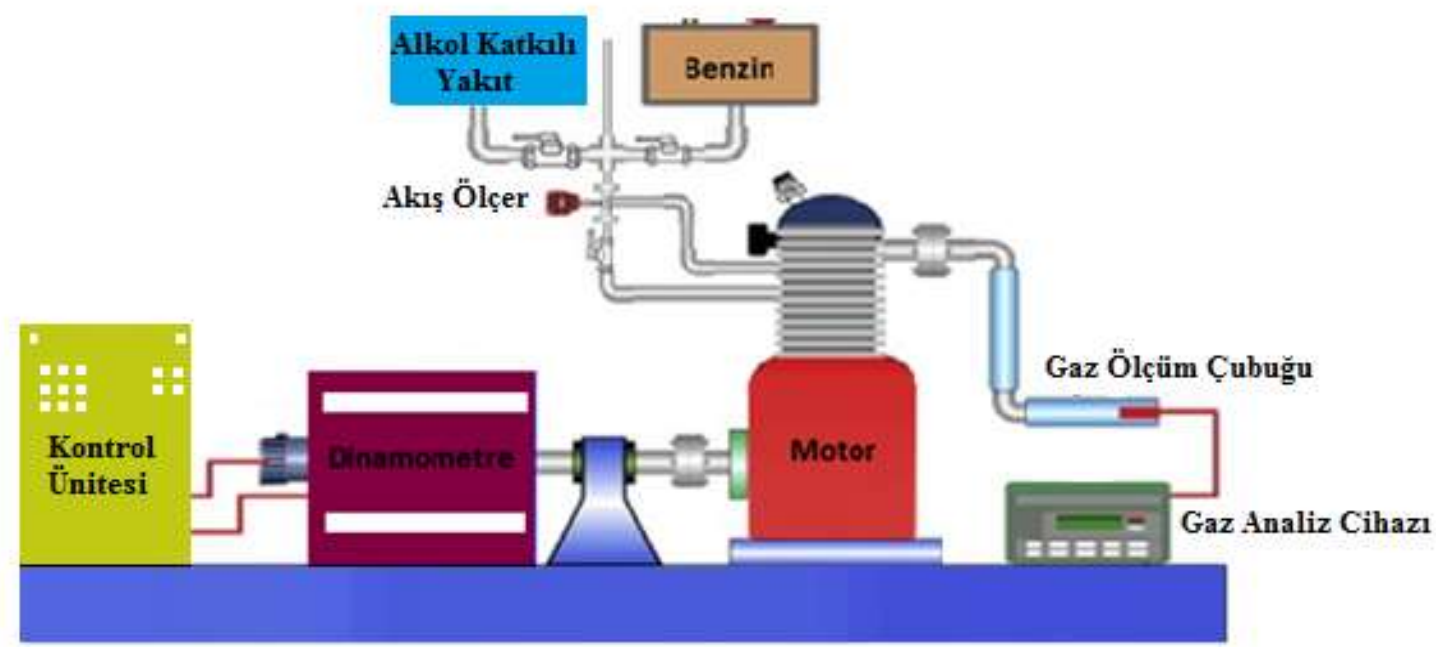

Şekil 2. Deney Düzeneği

Test yakıtlarının egzoz emisyonlarını ölçmek için teknik özellikleri Tablo 2'de verilmiş olan BEA 060 Model egzoz gaz analiz cihazı kullanılmıştır.

Tablo 2. Egzoz gazı analiz cihazının özellikleri

\begin{tabular}{|l|l|l|}
\hline Parametre & Ölçme aralığı & Hassasiyet \\
\hline $\mathrm{CO}(\%)$ (karbon monoksit) & $0-10$ & 0.001 \\
\hline $\mathrm{CO}_{2}(\%)$ (karbon dioksit) & $0-18$ & 0.01 \\
\hline $\mathrm{HC}(\mathrm{ppm})$ (hidrokarbon) & $0-9999$ & $1 \mathrm{ppm}$ \\
\hline $\mathrm{O}_{2}(\%)$ (oksijen) & $0-22$ & 0.01 \\
\hline $\mathrm{NOx}(\mathrm{ppm})$ (azot oksit) & $0-5000$ & $1 \mathrm{ppm}$ \\
\hline Lambda & $0.5-9.9999$ & \\
\hline
\end{tabular}




\section{Bulgular ve Tartışma}

Taşıtın hareket halinde iken karşılaştığı iç ve dış direnç kuvvetlerini yenmesi ve taşıtın çabucak hızlanabilmesi için ilk harekette momentin yüksek olması istenir

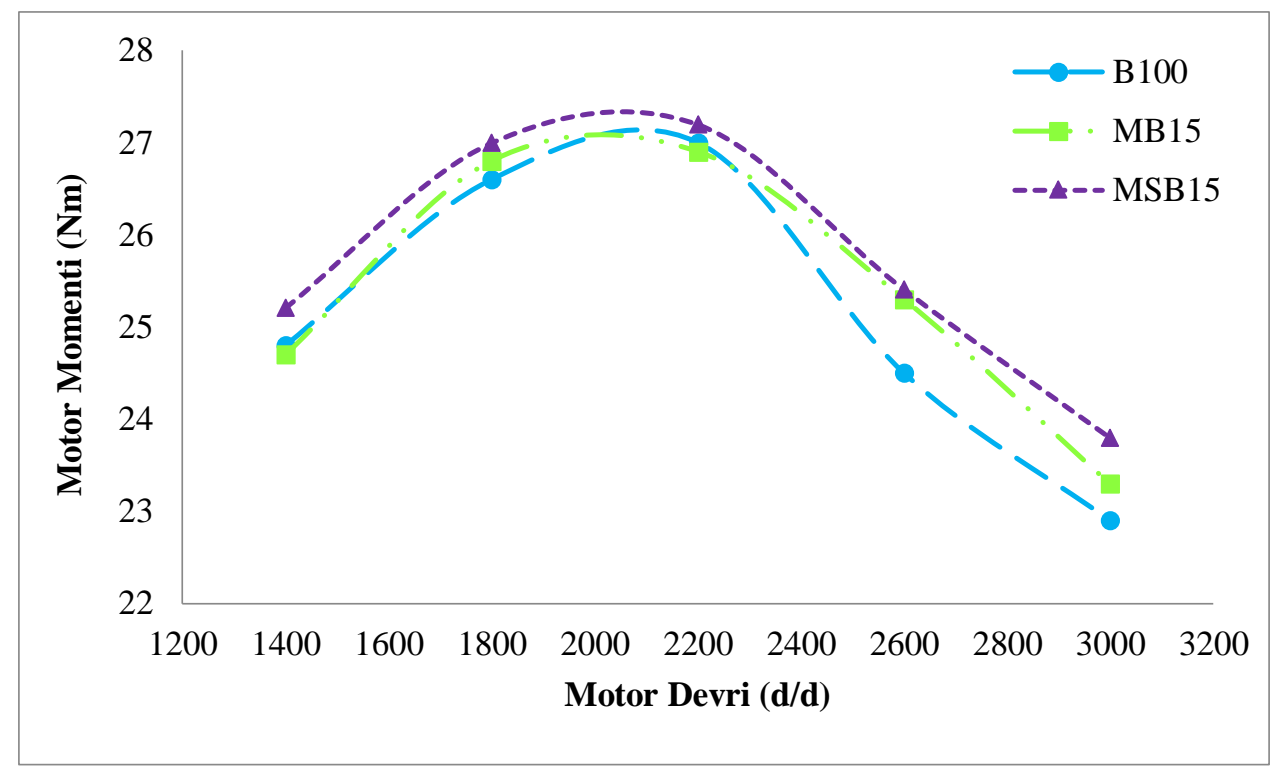

Şekil 3. Motor momentinin motor devrine bağlı değişimi

Şekil 3 incelendiğinde MB15 ve MSB15 yakıtlarından elde edilen momentler B100 yakıtından elde edilen momente göre daha yüksektir. Tüm motor devirleri için MSB15 yakıtının momenti, B100 ve MB15 yakıtlarının momentine göre daha yüksek olmuştur. Motor hızı arttıkça taşıt için gerekli olan motor gücü artacağından motor momenti de azalır. Şekilden de görüldügü gibi düşük motor hızlarında motor torku $2000 \mathrm{~d} / \mathrm{d}$ 'ya kadar artmakta ve bu devirden sonra motor hızı arttıkça bütün test yakıtları için motor momenti azalmıştır. Alkollerin gizli buharlaşma 1sıları ve oksijen içeriğinin yüksek olması, ayrıca volümetrik verimin iyileşmesinden dolayı MB15 ve MSB15 karışım yakıtlar benzine nazaran daha yüksek tork değeri göstermiştir. Literatürde incelendiğinde, alkol-benzin karışımları ile ilgili yapılan çalışmalar[24] da görüleceği gibi yüksek oktan sayısına sahip olan alkoller, tutuşma gecikmesinden dolayı silindirlerdeki 1sı transferi miktarının azalması nedeniyle benzine nazaran alkol katkılı yakıtların motor momenti artmaktadır.

Şekil 4'de motor gücünün motor devrine bağlı değişimi görülmektedir. Farklı devir sayılarındaki test yakıtları birbirleri ile kıyaslandığında tüm test yakıtların motor güçleri 2400 devire kadar fazla bir değişim göstermezken bu devirden sonra farklılıklar meydana gelmiştir. Tüm motor devirlerinin ortalaması alındığında MB15 karışım yakıtın motor gücü B100 yakıtına göre \%1.18 artarken MSB15 sodyum bor hidrür katkılı karışım yakıtın motor gücünde de \% 3.04 artma meydana gelmiştir. Motor gücü en yüksek 3000d/d da MB15 yakıtının kullanılmasıyla $7.32 \mathrm{~kW}$ olarak tespit edilmiştir. Motor hızının artması ile motor gücünde meydana gelen artmanın nedeni tam yük altında ateşleme avansının arttırılması ve benzin içerisine katılan metanol oranının artması ile yanmanın iyileşmesi ve motor çıkış gücünün de artmış olmasına bağlanabilir[25].

Şekil 5 de test yakıtların özgül yakıt tüketiminin motor hızına göre değişimi verilmiştir. Şekilde görüldüğü gibi en düşük özgül yakıt tüketimi $2600 \mathrm{~d} / \mathrm{d}$ da B100 yakıtıyla gerçekleşirken en yüksek ÖYT MSB15 yakıtı ile geçekleşmiştir. Tüm motor hızlarındaki yakıt tüketimlerinin ortalaması alınıp B100 yakıtı ile kıyaslandığında MB15 ve MSB15 karışım yakıtların özgül yakıt tüketimi B100 yakıtına göre sırasıyla \% 3.27 ve \% 7.52 artmıştır. Alkol-benzin karışımlı yakıtların özgül yakıt tüketimlerinin benzine göre yüksek olmasının nedeni, alkol katkılı yakıtların benzine göre daha düşük 1sıl değerlere sahip olmalarıdır[16]. 


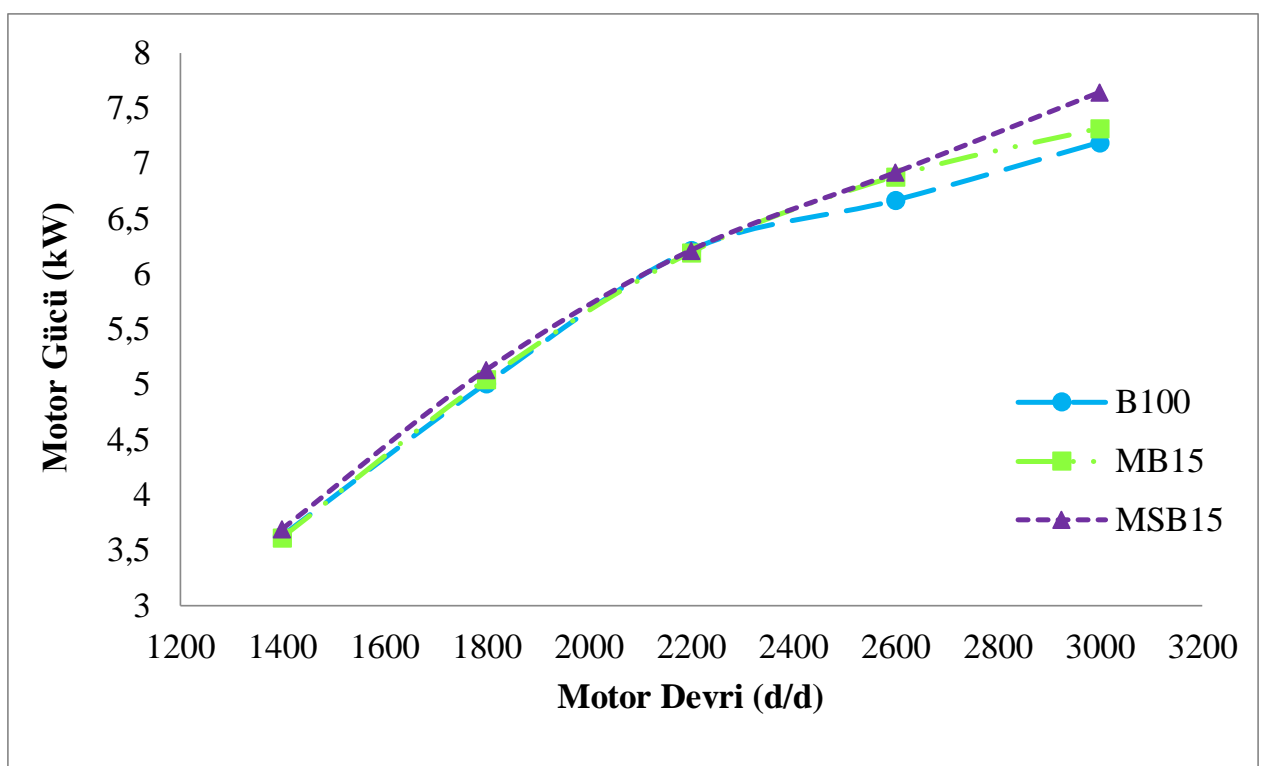

Şekil 4. Motor gücünün motor devrine bağlı değişimi

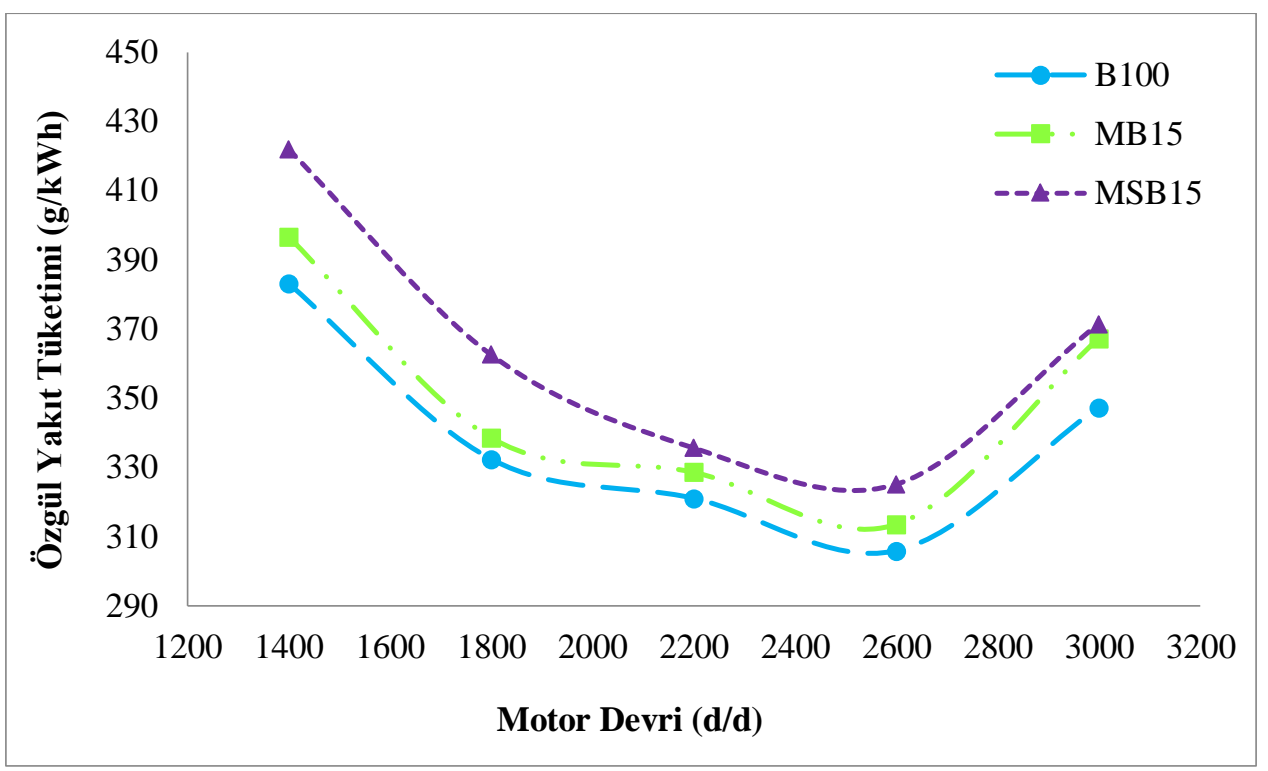

Şekil 5. Özgül yakıt tüketiminin motor devrine bağlı değişimi

$\mathrm{CO}, \mathrm{HC}$ ve $\mathrm{NO}_{x}$ göre motorlu taşıtlar tarafından çevreye daha fazla bırakılan bir emisyon olup bu emisyonu üreten başlıca kirletici kaynaklar arasında motorlu taşıtlar \%66 oranla ilk sirada yer almaktadır. CO emisyonu, hava/yakıt karışımındaki yetersiz oksijenden dolayı karbonun tamamı oksitlenemediğinden dolayı ortaya çıkan bir kirleticidir [23]. Şekil 6'da test yakıtlarına ait CO emisyonlarının motor devrine bağlı değişimi görülmektedir. Tüm motor devirlerinde en yüksek CO emisyonları deney motorunun benzin ile çalıştırılması ile elde edilmiştir. Karışım yakıtların CO emisyonları benzin ile kıyaslandığında, benzinli çalışmaya göre $\mathrm{CO}$ emisyonu bütün motor devirlerinde azalmıştır. CO emisyonu en az MSB15 yakıtı ile elde edilirken en fazla CO emisyonu B100 yakıtı ile elde edilmiştir. Alkol türevli yakıtlarda, metanolün karbon sayısı saf benzine göre daha az olması ve yapısında oksijen barındırması gibi sebeplerden dolayı CO emisyonları azalmaktadır. Dolayısıyla silindir içerisindeki alkol katkılı yakıtlarda bulunan metanolün yapısında bulundurduğu $\mathrm{O}_{2}$ yanmanın tam olarak gerçekleşmesini sağlamaktadır [26-27]. 


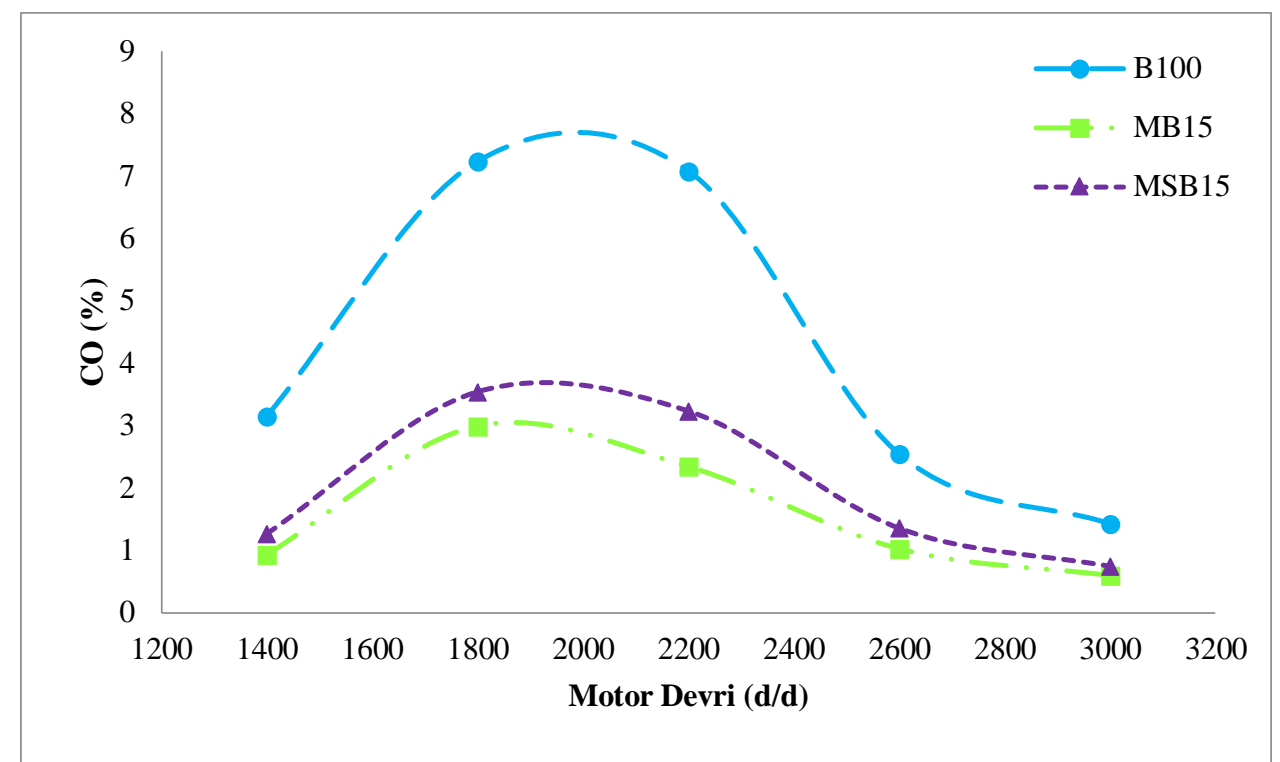

Şekil 6. CO'in motor devrine bağlı değişimi

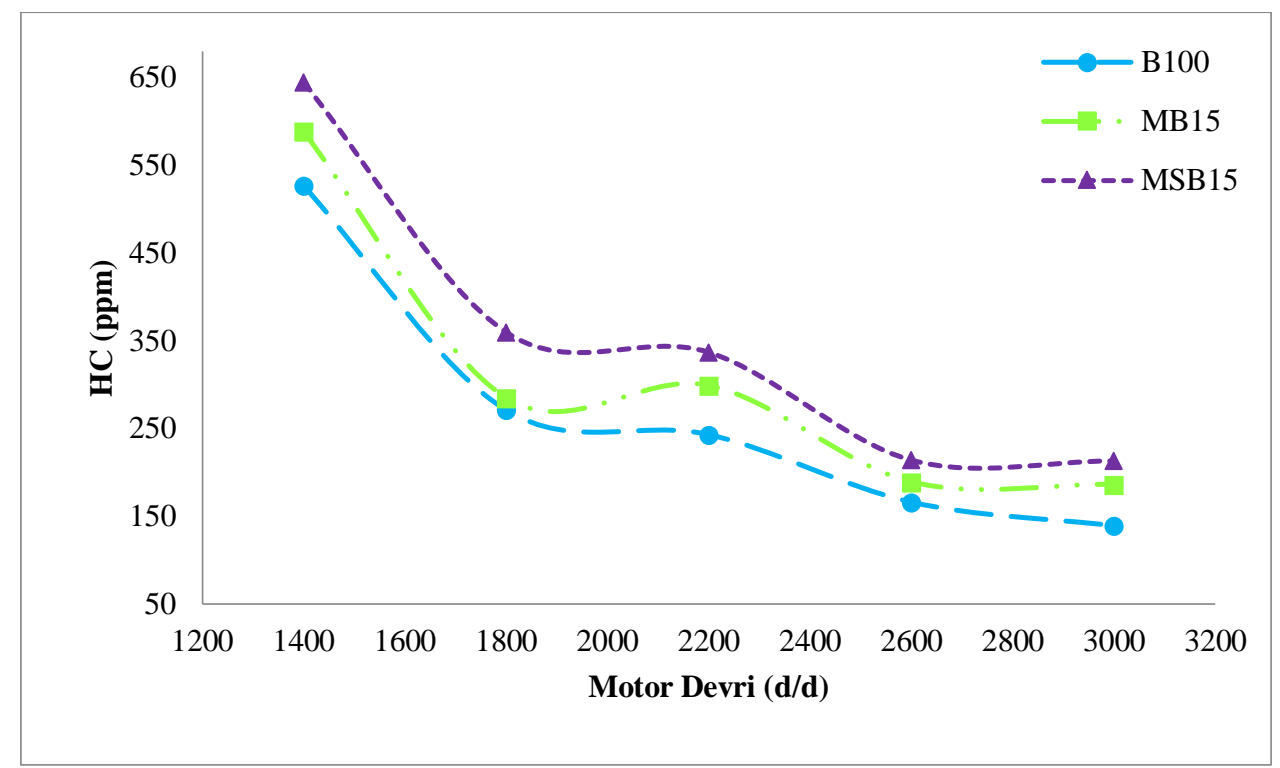

Şekil 7. HC'nun motor devrine bağlı değişimi

HC emisyonlarının oluşmasında, silindir cidarlarındaki yağ tabakası, yanma odasındaki karbon birikintileri, alevlerin yanma yüzeyinde sönmesi, fakir veya zengin karışımlar sonucunda oluşan eksik yanma gibi olaylarının tümü etkili faktörlerdir[28]. HC emisyonları, hem zengin karışımda tam yanmanın oluşabilmesi için yeterli miktarda oksijen olmadığından hem de fakir karışımda düşük alevin yayılması nedeniyle yakıt tam olarak yanmadan dışarı atıldığından artmaktadır [29]. Şekil 7'de motor devrine göre test yakıtların $\mathrm{HC}$ emisyonlarının değişimi verilmiştir. Grafik incelendiğinde, MB15 ve MSB15 karışım yakıtların HC emisyonu B100 yakıtına göre daha yüksek elde edilmiştir. Tüm motor hızlarında MB15 ve MSB15 karışım yakıtların HC emisyonları B100 yakıtının HC emisyonuna göre artmıştır. En yüksek HC emisyonu 1400d/d motor devrinde MSB15 yakıtı gerçekleşirken en düşük HC emisyonu $3000 \mathrm{~d} / \mathrm{d}$ motor devrinde B100 yakıtı ile elde edilmiştir. $\mathrm{HC}$ emisyonların artma nedenleri karışım yakıt viskozitelerinin artmasından dolayı yanmanın kötüleşmesi ve zengin karışımda motor yükünü artması olarak siralanabilir[30].

\section{Sonuç ve Öneriler}

Metanol-benzin ve $\mathrm{NaBH}_{4}$ katkılı metanol-benzin karışımlı yakıtların deney motorunda test edilmesi ile elde edilen sonuçlar dikkate alındığında; MB15 ve MSB15 karışım yakıtların motor momenti benzine 
göre artmıştır. Tüm motor devirlerinde ölçülen momentlerin ortalaması alındığında meydana gelen artış miktarı MB15 ve MSB15 karışım yakıtlarda sırasıyla \%0.95 ve \% 2.24 olmuştur. Düşük motor devirlerinde tüm test yakıtların motor gücü artarken yüksek motor hızlarında benzine göre karışım yakıtların motor gücü artış göstermiştir. Motor tam gaz altında çalışırken minimum özgül yakıt tüketimi 2600 d/d'da B100 yakıtının kullanılmasıyla gerçekleşirken aynı motor devrinde MB15 ve MSB15 karışım yakıtların özgül yakıt tüketimleri B100 yakıtına göre sırasıyla \% 3.27 ve \% 7.52 artmıştır. Ayrıca MB15 ve MSB15 karışım yakıtların egzoz emisyonları benzinli motorun emisyonları ile karşılaştırıldığında, CO emisyonları benzine göre sırasıyla \% 63.17 ve \% 52.65 azalırken HC emisyonları benzine göre $\% 15$ ve $\% 31.42$ artış göstermiştir.

\section{Yazarların Katkısı}

Yazarlar makaleye eşit oranda katkı sağlamış olduklarını beyan eder.

\section{Çıkar Çatışması Beyanı}

Yazarlar arasında herhangi bir potansiyel çıkar çatışması bulunmamaktadır.

\section{Araştırma ve Yayın Etiği Beyanı}

Yapılan çalışmada araştırma ve yayın etiğine uyulmuştur.

\section{Kaynaklar}

[1] Çelikten İ., Mutlu E., Solmaz H. 2012. Variation of performance and emission characteristics of a diesel engine fueled with diesel, rapeseed oil and hazelnut oil methyl ester blends. Renewable Energy, 48: 122-126.

[2] Kosar M., Ozdalyan Bulent., Celik M.B. 2011. The usage of hydrogen for improving emissions and fuel consumption in a small gasoline engine. Journal of Thermal Science and Technology, 31 (2): 101-108.

[3] Schifter I., Diaz L., Rodriguez R., Gomez J.P., Gonzalez U. 2011. Combustion and emissions behaviour for ethanol-gasoline blends in a single cylinder engine. Fuel, 90: 3586-3592.

[4] İçingür Y., Calam A. 2012. The effects of the blends of fusel oil and gasoline on performance and emissions in a spark ignition engine. Journal of The Faculty of Engineering and Architecture of Gazi University, 27 (1): 143-149.

[5] Calam A., İçingür Y., Solmaz H., \& Yamık H. 2015. A comparison of engine performance and the emission of fusel oil and gasoline mixtures at different ignition timings. International journal of green energy, 12 (8): 767-772.

[6] Kumar S., Cho J.H., Park J., Moon I. 2013. Advances in diesel-alcohol blends and their effects on the performance and emissions of diesel engines. Renewable and Sustainable Energy Reviews, 22: 46-72.

[7] Goldanica A., Faravelli T., Ranzi E., Dagaut P., Cathonnet M. 1998. Oxidation of oxygenated octane improvers: MTBE, ETBE, DIPE and TAME. The Combustion Institute, 27 (1): 353-360.

[8] Morganti K., Foong T.M., Brear M.J., Silva G., Yang Y., Dryer F. 2013. The research and motor octane numbers of liquefield petroleum gas. Fuel, 108: 797- 811.

[9] Foong T.M., Morganti K., Brear M.J., Silva G., Yang Y., Dryer F. 2014. The octane numbers of ethanol blended with gasoline and its surrogates. Fuel, 115: 727-739.

[10] Kish S.S., Rashidi A., Aghabozorg H. R., Moradi L. 2010. Increasing the octane number of gasoline using functionalized carbon nanotubes. Applied Surface Science, 256: 3472-3477.

[11] İçingür Y., Dost A. 2006. Experimental investigation of effects of propane/butane ratio on performance and emission in a spark ignition engine. Journal of The Faculty of Engineering and Architecture of Gazi University, 21 (2): 303-309.

[12] Çelik M.B., Çolak A. 2008. The use of pure ethanol as alternative fuel in a spark ignition engine. Journal of The Faculty of Engineering and Architecture of Gazi University, 23 (3): 619-626. 
[13] Badwal S.P.S., Giddey S., Kulkarni A., Goel J., Basu S. 2015. Direct ethanol fuel cells for transport and stationary applications - a comprehensive review, Appl. Energy, 145: 80-103.

[14] Balki M.K., Sayın C., Canakci M. 2014. The effect of different alcohol fuels on the performance, emissions and combustion characteristic of a gasoline engine, Fuel, 115: 901-906.

[15] Demirbas A. 2007. Progress and recent trends in biofuels. Prog Energy Combust Sci 33: 1-8.

[16] Eyidogan M., Canakci M., Ozsezen A.N., Alptekin E., Turkcan A., Kilicaslan I. 2011. Investigation of the effect, of ethanol-gasoline and methanol-gasoline blends on the combustion parameters and exhaust emissions of a spark ignition engine. J Fac Eng Arch Gazi Univ. 26 (3): 499-507.

[17] Ozsezen A.N., Canakci M. 2011. Performance and combustion characteristics of alcoholgasoline blends at wide-open throttle. Energy, 36 (5): 2447-52.

[18] Hsieh W.D., Chen R.H., Wu T.L., Lin T.H. 2002. Engine performance and pollution emission of an SI engine using ethanol-gasoline blended fuel. Atmos Environ. 36 (3): 403-10.

[19] Chen R. H., Chiang L. B., Chen C. N., Lin T. H., Cold-start emissions of an SI engine using ethanol-gasoline blended fuel, Applied Thermal Engineering, 31 (2011) 1463-1467.

[20] Ayhan V. 2006. Metanol-benzin karişimlarinin MgOZrO2 termal bariyer çemberli bir motorda performans ve emisyonlara etkisi, Yüksek Lisans Tezi, Sakarya Üniversitesi Fen Bilimleri Enstitüsü, Sakarya, 1-115.

[21] Yılmaz A., Şevik S. 2017. Sodyum Borhidrür (NaBH4) Destekli Bir Hidrojen/Hava PEM Yakıt Hücresi İle Elektrik Üretiminin Deneysel Analizi, Batman Üniversitesi Yaşam Bilimleri Dergisi, $7: 2 / 2$.

[22] Bilici M.S.Ü., 2004. Sodyum Borhidrür Üretim Yöntemleri, II. Uluslararası Bor sempozyumu, 23-25 Eylül, Eskişehir, 119-125.

[23] Yılmaz İ., Benli M. 2009. Metanolün Taşıtlarda Enerji Kaynağı Olarak Farklı Kullanım Yöntemlerinin İncelenmesi, Mühendis ve Makine, 50: 596.

[24] Masum B.M., Kalam M.A., Masjuki H.H., Palash S.M., Fattah I.M.R. 2014. Performance and Emission Analysis of a Multi Cylinder Gasoline Engine Operating at Different Alcohol-Gasoline Blends, RSC Advances, 4: 27898-27904.

[25] Shenghua L., Cuty Clemente E.R., Tiegang H., Yanjv W. 2007. Study of Spark Ignition Engine Fueled with Methanol/gasoline Fuel Blends", Applied Thermal Engineering, 27: 1904-1910.

[26] Ajav E.A., Akingbehin O.A. 2002. A Studey of Some Fuel Properties of Local Ethanol Blended with Diesl Fuel. Ibadan University Technology Faculty, Nijerya.

[27] Eyidoğan M. 2008. Etanol-Benzin ve Metanol-Benzin Karışımlarının Buji Ateşlemeli Bir Motorun Yanma Karakteristiği ve Egzoz Emisyonlarına Etkisinin İncelenmesi. Yüksek Lisans Tezi, Kocaeli Üniversitesi Fen Bilimleri Enstitüsü, Kocaeli, Türkiye, 26-27.

[28] Wu C.W., Chen R.H., Pu J.Y., Lin T.H. 2004. The Influence of Air-Fuel Ratio on Engine Performance and Pollutant Emission of An SI Engine Using Ethanol-Gasoline Blended Fuels. Atmospheric Environment, 38 (40 SPEC. ISS.): 7093-7100.

[29] Ergüder T.O. 2019. Erzincan şehir merkezinde Motorlu taşıt emisyonları kaynaklı Hava Kirliliğinin düzeyinin Araştırılması. Yüksek Lisans Tezi, Erzincan Binali Yıldırım Üniversitesi, Fen Bilimleri Enstitüsü, Erzincan, 1-122.

[30] Kodah Z., Soliman S. 2000. Combustion in a Spark Ignition Engine. Applied Energy, 66: 237250. 